\title{
THE ROLE OF SUBAK (TRADITIONAL FARMERS INSTITUTION IN BALI) TO FARMERS' WELFARE AFTER THE CULTURAL LANDSCAPE OF SUBAK INSCRIBED AS A WORLD HERITAGE
}

\author{
Suasih Ni Nyoman Reni*, Darma I Ketut, Sara I Made, Lecturers \\ Faculty of Economics, University of Warmadewa, Denpasar, Bali, Indonesia \\ ${ }^{*}$ E-mail: reni kenanga@yahoo.com
}

\begin{abstract}
In 2012, the UNESCO inscribed cultural landscape of subak as a world heritage, so that farmers in the region are not permitted to convert their rice fields. This study aimed to analyze the role of government, and the institutional role of subak on the farmers' welfare in the area of subak which is inscribed as world heritage, namely in the Pakerisan watershed. The analysis technique used is descriptive analysis and inferential analysis by SEM-PLS approach, where the role of subak institution functioned as a moderator on the effect of the government's role to the farmers' welfare. The results show that the role of subak strengthens the government's role to the farmers' welfare in the area of landscape subak which is inscribed as world heritage. Government program to achieve sustainable agricultural development can synergy with subak as an institutional which is control the watering system, so that the program can be received and adopt by farmers.
\end{abstract}

\section{KEY WORDS}

Subak, government, farmers, welfare, institution.

The agricultural sector in Indonesia is dominant built by small-scale farmers. Smallscale agricultural impede farmers to increase their income, so it's difficult to get out of the cycle of poverty. Poor farming communities in addition to the narrow farming, is also caused by low productivity, limited infrastructure, low accessibility to capital, technology, information and markets, also low capacity of farmers.

Based on the orientation of agricultural development in Indonesia, which currently refers to the agribusiness system, the role of agricultural institutions, especially institutions of farmers, determine the success of agricultural development which leads to the farmers' welfare. Institutional farmers in rural contributing among other things to: acceleration of socio-economic development of farmers; accessibility of agricultural information; accessibility to capital, infrastructure, and markets; and the adoption of agricultural innovations. Moreover, the existence of institutional farmers will also be easier for the government and stakeholders (stakeholders) others to facilitate and provide reinforcement to the farmers.

The welfare of the farmers community is still far below expectations due to lifestyle subsistence farmers communities and believes that with adequate daily food needs they had been satisfied. Whereas the level of welfare in life can not be measured only by insufficient daily needs. The fundamental problem behind the problem of the farmers in Indonesia is the helplessness of farmers to negotiate the results of agricultural production (Anggriani, 2011). Farmers if farming individually will continue to be on the weak side for individual farmers, because they just manage small and scattered land size and ownership of capital is low (Sesbany, 2009). For that, the government needs to pay attention to the institutional strengthening through farmer groups with the aim of strengthening the bargaining position of farmers, both in the institutional and capital. Maintaining environmental sustainability (include ricefield) is one of eight goals of the Millenium Development Goals (Saskara and Marhaeni, 2017).

As long as it has a lot to form the farmers institutions in the village, but the study results from Agustian, et al. (2003); Purwanto et al. (2007); Syahyuti (2003); Zuraida and Rizal (1993) shows that institutional farmer in the village generally does not go well due to several causes. Farmer groups are generally established based on technical interest to facilitate 
coordination if there is an activity or a government program, almost exclusively oriented programs alone, so less to ensure the sustainability and self-reliance groups. Participation and cohesiveness of the group members in group activities is relatively low. This is shown on the attendance of members in group meetings tend to be low, reaching only $50 \%$. Management of productive activity is individual group members. The group as a forum for joint activities has been unable to become unifying container activities of members and member simultaneously fastener needs. This causes more prominent individual productive activities, whereas on the other hand the activities of group members faced with the difficult issues of capital, volatility and limited marketing channels. Formation and institutional development are not based on local social capital with the principle of local autonomy which will be achieved through the autonomy principles and empowerment. Formation and institutional development based on similar blue print approach, with little regard for local institutions that already exist, and the typical characteristics of the economic, social and political running. Formation and institutional development based on approaches that topdown lead to low participation. Institutional built limited only to strengthen the bonds of horizontal, rather than vertical, with a membership of people who have the same activity. Horizontal bond aims to establish cooperation in the next stage is expected to increase bargaining power. Willfully vertical bond market mechanism, which is difficult to reach government authorities. Eighth, provide guidance to the institutions that have formed tend to be individual and only to administrators only. Institutional development is more frequent use of structural lines, and weak from the development of its cultural aspects. The organizational structure previously built when the attitude of self-organization has not grown at the board and its members.

One of the institutions that grow and develop agriculture in Bali is subak. Subak during this activity mostly limited to setting irrigation system, but there is a desire to develop the activity of subak as an Economic Enterprise Institution of subak (LUES). Subak existed long ago in Bali based on the philosophy Tri Hita Karana or three harmonious relationship which is cause happiness, i.e. Parahyangan (harmonious relationship between man and God), Pawongan (harmonious relationships with fellow human beings), and Palemahan (harmonious relationship between humans and the environment). Is a living mechanism or the Balinese way of life, based on Hindu religion and culture of Bali, among them there is the ceremony of new rice farms start planting until harvest ceremony arrived?

Since June 29, 2012, subak became the core of agricultural activities in Bali set by the United Nations (UN) through one organization, namely the United Nations Educational, Scientific, and Cultural Organization (UNESCO) to World Heritage (Kemendikbud, 2013). Sulistyanto (2012) explained that Indonesia benefited from a site designated as world heritage. There are several area of landscape subak which is inscribed as world heritage as follows as: (1) Area of Ulun Danu Batur Temple; (2) Area of Batur Lake; (3) Area of landscape subak in Pakerisan watershed; (4) Area of landscape subak Catur Angga Batukaru; and (5) area of Taman Ayun Temple.

The establishment of Subak as world heritage included in the category of cultural landscape entitled "The Cultural Landscape of Bali Province: the Subak System as a Manifestation of the Tri Hita Karana Philosophy" (Cultural Landscape of Bali Province: System subak as manifestations of Philosophy Tri Hita Karana). There are two rules of world heritage to be used as guidelines in the management and utilization of world heritage region, that authenticity rules while maintaining the authenticity, and sustainability rules to ensure sustainability (Windia and Wiguna, 2013).

Subak's unique culture that has elements of cooperativeness and the concept of Tri Hita Karana is one factor that led to UNESCO recognizes subak as world heritage. Subak Pulagan is one of the world heritage drained by Pakerisan Watershed, located in the village of Tampaksiring of Gianyar Regency. Farmers in Subak Pulagan hope with the granting as world culture farmers and community around there will get benefits. Farmers are not too bother with the government's efforts in the establishment of subak as world heritage, as long as the degree to contribute and did not give a new burden in their lives (Sarita et al., 2013). The views of farmers in a flat tone as world heritage actually illustrates that the title does not 
give a great influence on their lives. The government continues to aggressively fight for the awarding of the subak as one world heritage regardless of the condition of the farmers (Subagia, 2011).

The government through BULOG institution and vertical agencies below (DOLOG and Sub DOLOG) making floor price policy for dry grain milled and the ceiling price for rice which is essentially an investment in the market mechanism. The government will conduct market operations if the price of rice on the market rated far beyond the highest price they can harm consumers. Instead the government periodically fixes the base price of paddy; the farmers are motivated to increase its production. This policy is basically aimed at providing justice for consumers and producers.

Predicate as world heritage is expected to be a positive influence on common interests. When viewed from the economic side, the degree as world heritage is considered to increase the income and government attention to the situation of farmers in DAS Pakerisan, especially Subak Pulagan. There are consequences in addition to gains on WBD predicate, which is to preserve the subak. There are some expectations of farmers in Subak Pulagan after the status as world heritage can be categorized in three aspects, namely mindset, social and material aspects (Sarita, et al., 2013). Aspects mindset, namely the increasing awareness of the public at large in order to preserve water control system, have knowledge of world heritage and UNESCO, as well as the increasing attention of government to provide solutions to the problems experienced by farmers. The solutions are expected to include: (1) fund that will motivate the productivity of the land; (2) help repair irrigation networks and physical building water control system; (3) easily necessities of production and marketing of the crop; (4) simakrama or meeting with farmers in order to increase farmers' income; (5) training can improve the performance of the farmers; (6) a program of scholarships for the children of farmers who excel; and (7) improving and enhancing infrastructure such as roads in subak. Furthermore, the social aspect is no conflict between members' internal subak and among subak as institution, their solution to suppress land use, and the provision of the interaction space. Aspects of material that is free tax of ownership land or rice field in subak, subsidization of production facilities and other conveniences, as well as adequate irrigation water and irrigation networks and physical facilities cared for and treated. Related conveniences expected by farmers in Subak Pulagan, i.e.: (1) free of land ownership tax, which is considered as a form of appreciation to farmers of subak has been keeping his farm; (2) subsidies or help plant seeds and organic fertilizer; (3) obtain farm loans as capital in the next planting season; (4) ease of obtaining the means of production which correspond to a time trying farmer; (5) access information about the price of grain and rice; (6) collateral for the risk of crop failure or agricultural insurance.

Farmers should be able to optimize the role and functions of the organization as well as agricultural institutions in an effort to increase production, one of them to obtain financial support (credit) and social support (Jeckoniah et al., 2013). As described by Hayami and Vernon (1985) that in order to boost agricultural development in developing countries is very important to do the changes in the institutional elements and farming techniques.

Government plays an important role in agricultural development in Indonesia, in addition to other roles that have been attached to both regulatory role, the role of counterweight, and a supervisory role. Such development is one done through institutional development efforts of farmers to realize the welfare of farmers, considering that farmers were impressed as inferior profession. Issues of equity, marginality and poverty can be easily seen, both in terms of income, in terms of employment and in terms of effort. The classification society based on such aspects have a generally pyramid shape with the highest number is the group under which the weak, i.e. low income, low workers, small entrepreneurs and poor farmers.

Government will continue to improve agricultural productivity, due to decreased interest in becoming farmers, and land conversion will continues to happen in Bali. Increasing agricultural productivity is no longer a guarantee would provide a decent profit for the farmer if the absence of equality of income between farmers engaged in the on farm sub-system to agribusiness in the upstream and downstream sub-sector. Income equality can only be 
achieved by increasing farmers' bargaining position. This can be done if the farmers do not work individually, but gather strength in an institution that is truly able to channel their aspirations. In an effort to raise awareness about the importance of farmers gathering strength together, then the government acting through agricultural extension services for institutional building. Farmers' institutions can only play if the optimal growth and development is controlled entirely by the farmers so that farmers have been subjected to the process (Jamal, 2008).

Therefore it is very important to conduct a study on the farmers' welfare in the world's heritage area, so that farmers do not perform conversion of agricultural land. The purpose of this study was to analyze the role of subak as a traditional farmers' institution in moderating the role of government to the farmers' welfare.

\section{THEORETICAL REVIEW}

The Role of Government. Adam Smith with his classic view in Hindriks et al. (2006) explains that the government has three main roles, namely: (1) maintenance of internal security and defense, (2) conduct judiciary, and (3) provide the goods that are not provided by the private sector. Hindriks et al. (2008) concluded that in the modern era, the role of government is more likely to be categorized in the following three areas:

- Role allocation, the government as a provider of public goods and services;

- The role of distribution, that the government seeks the empowerment of low income communities;

- Stabilizing role, which the government provides various types of subsidies.

Hindriks et al (2006) also outlines that the government has four main roles, namely:

- The role of the allocation of resources, including the determination of the absolute and relative size of government in the economy and the provision of public goods and social welfare services for the community;

- The role of regulators, including the preparation of regulations and procedures required by the community about the business to facilitate business activity and the right to private ownership of the role of social welfare, include policies that encourage social equality in the country concerned as taxation, social security (transfer payment) and the provision of some public goods mix for the community;

- The role of macroeconomic management, namely facilitating the general stability and economic prosperity of the country through policies to promote stable economic growth, full employment, low inflation, and balance of payments stability.

The role of government occurs as a result of the rights and obligations of the government to regulate the order of statehood. Broadly speaking, the government plays a role in the field of the allocation, distribution and stabilization.

Developing the farmers' institutional capacity through agricultural extension institution is the task of the government. Indonesian Law No. 16 Year 2006 about the Counseling System of Agriculture, Fisheries and Forestry, describe the task in the Section 11 (1) c, described: facilitating the development of institutional and community forums for the main actors and entrepreneurs to develop their business and provide feedback to local governments. Also described in Section 13 (1) e, described: to develop and facilitate institutional and forum activities for the main actors and businessmen.

Farmers' institution is the means at the same institutional goals of agricultural extension (Albrecht, et al., 1989 and Mosher, 1991), so its presence is indispensable. Condition usually arises from institutional dilemma of extension due to the bias of interest. Agricultural extension, both government employees and private sector, is a member or staff of the institution who appointed him not infrequently official interest-oriented rather than the interests of farmers in their work. In connection with this situation, the strengthening of the institutional capacity of farmers require institutional commitment to education, especially institutional government agricultural extension, to carry out tasks that should (Anantayu, 2011). 
The government has a wide range of different roles in various fields of development and life of the nation state. In agriculture, the government can be considered to have a role and function in terms of regulation, guidance, control, supervision, and a counterweight.

The Role of Subak as Traditional Farmers Institution in Bali. Institutions are believed by most economists could be a source of efficiency and economic progress (Yustika, 2010). Related application of new institutional economics (NIE) on agricultural policy research in developing countries, Kherallah and Kirsten (2001) gave some examples of cases that use institutional economics approach to the analysis, as well as an opportunity to address some of the economic problems difficult to solve by the neoclassical approach. Some examples of cases referred to, that is:

- Contract farming and vertical linkages of farmers (contract farming and other vertical linkages),can be analyzed with the theory component of institutional economics is the theory of the contract (contract theory) to analyze the problems of contractual relations in agriculture in developing countries; relations agency (agency relationships: principle agent problems and incomplete contracts) to analyze the relationship between the farmer (agent) and coordinator of the vertical/integrator/agribusiness (the principal); transaction costs to analyze the transaction costs which occur on agricultural contracts;

- Cooperation and farmers organizations (Cooperatives and other farmer organization), can be analyzed by component institutional theory, namely the right of ownership (property rights) and collective action, transaction costs, and organizational/contract theory, can provide information on the design of the organization and co-operation in order to avoid failure;

- The behavior and performance of the merchant (trader's behavior and performance), can be analyzed by the component of institutional theory that transaction costs and social capital that can be used to answer a related question: whether the response of institutional and choice of trading contracts is efficient?; whether the rules of government in cutting transaction costs and reduce market risks?; institutional how needed to develop market efficiency?

- Access to agricultural inputs and rural credit markets, can be analyzed by components, namely institutional theory and the theory of agency information that is used to identify the type of institutions that could expand credit for rural households.

- Institutions that can provide risk management and market information, by analyzing the necessary institutional types (including formal and informal) to manage market risk in developing countries.

Farmers institutional are farmers institutions which are in the region of locality (local institution), which is a membership organization or cooperation, the farmers who are members of group cooperation (Uphoff, 1986). Further described by Anantayu (2011) that these institutions include a broad understanding that in addition includes the notion of farmers' organizations, as well as the 'rules' (role of the game) or rules of behavior that determine the patterns of action and social relations, as well as social cohesion which is a concrete manifestation of the institution.

Esman and Uphoff in Garkovich (1989) states that the farmer institution established basically have several roles, namely: (1) inter organizational task to mediate between society and the state; (b) resource tasks includes the mobilization of local resources (labor, capital, materials, information) and its management in achieving community goals; (3) service tasks includes a service request that describes the purpose of development or coordination request of local communities; and (4) extra organizational tasks requires the existence of local demand for bureaucracy or outside the community against bureaucratic organization or organizations outside the community against interference by outside agencies.

Agricultural institutions that do not support is one of the problems in the management of agricultural resources, where institutional referred to one of them is institutional farmers themselves. Therefore, Anantayu (2011) expressed the need for institutional development of farmers that is based on the premise that: (1) the farming process requires human resourcebacked resilient infrastructure, equipment, credit and so forth; (2) institutional development of 
farmers is more complicated than the management of natural resources as it requires supporting factors and units of production; (3) agricultural activities cover three series, namely the preparation of input, transforming inputs into products with labor and management effort, and assign the output to be valuable; (4) agricultural activities require support in the form of policies and institutions of the central and local levels; and (5) the complexity of the farm, which includes the business units and institutions, difficult to achieve optimal conditions.

Resource management by farmers regarding farm input arrangement, production processes, as well as the output so as to achieve high productivity. Own agricultural business activities include input, output and output (Uphoff, 1986). In the management of the factors of production, the production process, until the necessary institutional agricultural processing farmers. Agribusiness activities will be successful if farmers have sufficient capacity. In order to achieve optimum productivity and efficiency of farmers have collectively doing business together. It is necessary for the understanding of an institution at the farm level. Traditionally, farmers have been developing community institutions from generation to generation, but the challenges of the times demand a more appropriate institution to meet the needs of farming communities. Effective farmer institutions is expected to support agricultural development. Anantayu (2011) confirms that at the farm level necessary institutions as: (1) a vehicle for education; (2) commercial activities and organization of agricultural resources; (3) management of public property; (4) defend the collective interests; and (5) others.

Mosher (1991) believes that the joint activities (group action or cooperation) by farmers is a factor facilitating agricultural development. Activities along with togetherness is necessary if it would be more effective in achieving the desired goals together. Furthermore Anantayu (2011) explains that the institutional presence of farmers is based on the cooperation can be done by farmers manage agricultural resources, among others: (1) processing, in order to more quickly, efficiently and cheaply; (2) marketing, will convince buyers on the quality and improve the bargaining position of farmers; (3) buying, in order to get a cheaper price; (4) machine sharing, will lower the cost of purchase of the tool; (5) cooperative services, to provide services for the mutual benefit so as to improve the welfare of members; (6) cooperative banks; (7) cooperative farming, will obtain higher profits and uniformity of products produced; and (8) multi-purpose cooperatives, which was developed according to the same interests of farmers.

Farmers' welfare. Welfare theory by Albert and Hannel (2005) can be generally classified into three types, namely classical utilitarian, neoclassical welfare theory, and new contractarian approach. Classical utilitarian aproach emphasizes that the satisfaction or pleasure a person can be measured and grow. The principle of an individual is to improve as much as possible the level of welfare, while for the public is that the increase in the welfare of the group is the main principle. While the approach of neoclassical welfare theory explaining that welfare functions is a function of all individual satisfaction. Furthermore, the developing and emerging welfare theory approach contractarian new that elevates the maximum freedom in individual lives, with an emphasis that will maximize individual freedom to pursue their concept of goods and services without any interference.

According to the theory, as quoted Euis Sunarti (2007), described that the family will function when running a sustainable and adaptive function, function of the goal attachment, integration function and latency function. Adaptation functions that the acquisition of resources from outside the family to meet the needs of the family. Goal attachment functions. is to determine the family goal. Integration function is maintained integration and solidarity involve these elements to control and maintain the system and to prevent a major disruption in the family system. Latency functions whereby stored energy is distributed within the family system. As the four functions do not run in the family farmer, the family welfare will be difficult to materialize.

Welfare of farm families is the goal of agricultural development and national development. In simple terms it can be said that the family farmer is said to be improved if the basic needs of its members. Welfare is closely related to the functioning of the family. 


\section{FRAMEWORK AND HYPOTHESES}

Institutional capacity allegedly moderating the role of government relations for the farmers' welfare. Institutional organization and poor farmers is one of the causes of poverty of farmers. Anantayu (2011) explains that the institutional presence of farmers for farmers are becoming a necessity to improve their quality of life, dignity and status. Most businesses in Indonesia are farmers and small businessmen that when assembled in a strong economic organization will benefit (welfare).

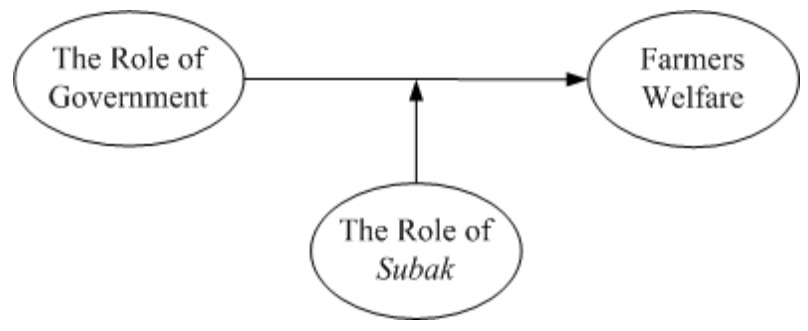

Figure 1 - Conceptual Framework

Within facilitate various government programs to farmers, as well as strengthen the bargaining position of farmers who have limited land area, the farmer needs to have institutional farmer. Anantayu research results (2011) states that the institutional presence of farmers for farmers has become a necessity to improve their quality of life, the dignity of farmers. Agricultural counseling needs to be designed to give content on strengthening the capacity of the individual farmer as well strengthening the institutional capacity of farmers.

Furthery, Listyati et al. (2014) explained that related to institutional strengthening to increase bargaining position of farmers in cocoa marketing system mentioned that government in institutional system of farmer group combination model is giving capital aid, role in provision of agricultural extension and agricultural production suggestion.

The ultimate goal of various efforts to increase agriculture, one of which is to realize the welfare of farmers. Scholar and Munir (2008) explained that there are several indicators to assess farmers' welfare, such as the share of agricultural income, the share of food expenditure, the purchasing power of farm households, the level of food security, and the exchange rate of farmers.

Based on the conceptual framework of the research, there are two hypotheses in this study, namely: (1) the role of government have significant positive effect on the farmers' welfare; and (2) The role of subak are influential moderate the role of government to the farmers' welfare.

\section{METHODS OF RESEARCH}

In this study, there are three types of variables: 1) the role of government as exogenous variables, 2 ) the role of subak as moderating variable, and 3 ) farmers' welfare as endogenous variables. Perceptions of respondents were measured with instruments that had been prepared in the form of the statement, it is valid and reliable, rated using a Likerts Scale. Range of rating ranging are from strongly disagree to strongly agree with the statement filed with detail range of values as follows: $S S=$ strongly agree (5), $S=$ agree (4), CS = quite agree (3), TS = disagree (2), and STS = strongly disagree (1).

Data Analysis Technique. This study uses a quantitative analytical approach. Quantitative analysis is using descriptive statistics and regression analysis with moderating variable, as shown in the following equation:

$$
F W=\beta 0+\beta 1 R G+\beta 2 R S+\beta 3 R G R S+\varepsilon
$$

Where: FW = farmers' welfare; RG = the role of government; $R S=$ the role of subak; $\beta 0, \beta 1$, $\beta 2, \beta 3=$ parameter; $\varepsilon=$ error. 


\section{RESULTS OF STUDY}

Descriptive Analysis. Ferdinand (2012) states that to be able to interpret a perceptual index can use the three box method criteria. Further Ferdinand (2012) also provides a range of three box method following criteria: $10 \%-40 \%$ expressed as bad/low appreciation; $41 \%$ $70 \%$ expressed as moderate appreciation; and $71 \%$ - $100 \%$ expressed as good/high appreciation. The result of descriptive analysis to the latent variables of the role of government, the role of subak, and farmers' welfare in Subak Pulagan, Pakerisan Watershed is describes as Table 1.

Table 1 - Perception index of research variable

\begin{tabular}{|l|c|}
\hline \multicolumn{1}{|c|}{ Variable / Indicator } & Perception Index \\
\hline 1. Perception index of variable "the role of government" & 63.26 \\
\hline Regulate function & 61.70 \\
\hline Coaching/educate function & 65.92 \\
\hline Control function & 65.20 \\
\hline Supervise function & 61.52 \\
\hline Balancing function & 61.97 \\
\hline 2. Perception index of variable "the role of subak" & 77.49 \\
\hline Clarity the purpose of subak in the implementation of Tri Hita Karana & 81.35 \\
\hline The role and function of subak to set the farming system & 80.18 \\
\hline Agricultural innovation of subak institution & 68.43 \\
\hline Sustainability of subak institution & 80.00 \\
\hline 3. Perception index of variable "farmers' welfare" & 66.14 \\
\hline Farmers income structure & 64.84 \\
\hline Farmers expenditure of primary needs/food & 61.70 \\
\hline Purchasing power of farmers family & 64.66 \\
\hline Food sovereignty & 73.36 \\
\hline
\end{tabular}

Table 2 - Outer model evaluation (loading factor and cronbach alpha value)

\begin{tabular}{|l|l|l|l|}
\hline Variable / Indicator Symbol & Loading Factor & Cronbach Alpha & Result \\
\hline The role of government (RG) & & 0.877 & Reliable \\
\hline RG1 & 0.862 & & Valid \\
\hline RG2 & 0.787 & & Valid \\
\hline RG3 & 0.818 & & Valid \\
\hline RG4 & 0.791 & & Valid \\
\hline RG5 & 0.837 & & Valid \\
\hline The role of subak (RS) & & 0.924 & Reliable \\
\hline RS1 & 0.890 & & Valid \\
\hline RS2 & 0.913 & & Valid \\
\hline RS3 & 0.893 & & Valid \\
\hline RS4 & 0.912 & & Valid \\
\hline Farmers' welfare (FW) & & 0.928 & Reliable \\
\hline FW1 & 0.911 & & Valid \\
\hline FW2 & 0.905 & & Valid \\
\hline FW3 & 0.920 & & Valid \\
\hline FW4 & 0.893 & & Valid \\
\hline
\end{tabular}

Respondents' perceptions index for the role of government variable is moderate. Variable of the role of subak with high perception index, while the perception index for farmers' welfare variables is moderate.

Outer Model Evaluation (Measurement Model). Test data quality obtained from the use of research instruments can be evaluated through the validity test and reliability test. Rules of thumb used are loading factors that must be greater than or equal to 0.40 (Hair et al, 1998). Test reliability by looking at the cronbach alpha coefficients. Reliability value seen from cronbach alpha of each research instrument ( $\geq 0.60$ considered reliable).

Inferential Analysis. Analysis of direct influence and direct influence with moderation can be seen from the analysis of path coefficient value shown in Table 3. 
Table 3 - Path Coefficient

\begin{tabular}{|c|c|c|c|c|c|}
\hline Construct & $\begin{array}{c}\text { Original } \\
\text { Sample (O) }\end{array}$ & $\begin{array}{c}\text { Sample } \\
\text { Mean (M) }\end{array}$ & $\begin{array}{c}\text { Standard } \\
\text { Deviation } \\
\text { (STDEV) }\end{array}$ & $\begin{array}{c}\text { T Statistics } \\
(\mid \text { OSTERR|) }\end{array}$ & $\begin{array}{c}\text { P } \\
\text { Values }\end{array}$ \\
\hline $\begin{array}{c}\text { The role of government } \rightarrow \\
\text { Farmers' welfare }\end{array}$ & 0.109 & 0.107 & 0.063 & 1.735 & 0.083 \\
\hline $\begin{array}{c}\text { The role of subak } \rightarrow \text { Farmers' } \\
\text { welfare }\end{array}$ & -0.057 & -0.060 & 0.056 & 1.020 & 0.308 \\
\hline $\begin{array}{c}\text { The role of government * The } \\
\text { role of subak } \rightarrow \text { Farmers' } \\
\text { welfare }\end{array}$ & 0.084 & 0.084 & 0.022 & 3.878 & 0.000 \\
\hline \begin{tabular}{c} 
wolf \\
\hline
\end{tabular}
\end{tabular}

Analysis of the influence of the role of government to the farmers' welfare does not show a significant relationship as shown in Table 3 with regression coefficient of 0.109 . The null hypothesis is accepted because the $p$-value of 0.083 is greater than the 0.05 significance standard. This means that the role of the government directly has no significant effect to the farmers' welfare.

Table 3 shows that the regression coefficient between the role of subak to farmers' welfare with coefficient of -0.057 with t-statistic 1,020 and p-value 0.308 so it is not significant. The regression coefficient between the role of government interaction with the role of subak to farmers' welfare is 0,084 with t-statistic 3,878 and p-value 0,000 which means the relationship is significant.

\section{RESULTS AND DISCUSSION}

The result of data analysis shows that the influence of the role of government to the farmers' welfare with moderation of the role of subak is positive and significant. Given that: (1) the role of the government directly has no significant effect on the farmers' welfare; (2) directly, the role of subak has no significant effect on the farmers' welfare; and (3) the interaction of the role of government and the role of subak directly has a positive and significant effect on the welfare of farmers, the the role of subak is pure moderator.

An institutional or community organization generally grows and develops in an ecological system where the community lives and conducts various productive activities (Suradisastra dan Dariah, 2013). One example of agricultural institutions according to Suradisastra dan Dariah (2013) is a subak organization in Bali that at the beginning of its history relied on water as a binding resource for agricultural activities. Subak organization as a socio-cultural organization that regulates the irrigation system since hundreds of years, can be explained that subak organization formed from harmonious relationships among fellow farmers (Suasih, et al., 2017). The binder has now grown further, and its binding resources no longer have to be water or water sources, but also dry land (which develops into subak abian in Bali), other social, economic, and technical resources. The modern subak is now a cooperative institution operated communally through its member representatives, and supporting resources. Subak development is also growing, including the financial resources derived from tourism and hospitality activities, as well as the resources of other nonagricultural sectors.

The success of agricultural development, especially food crop agriculture in Bali, can not be separated from the role of subak institutions. Subak is an organization that regulates irrigation of rice fields in Bali, even Darmanta, et al. (2013) defines subak as a Balinese customary law community that regulates in the field of regulating water for paddy fields from a water source within a region. Furthermore, Sutawan, et al. in Pitana (1993) defines a subak as a wetland farmer's organization obtaining irrigation water from a common source and possessing one or more Bedugul temples (for worshiping Dewi Sri, the manifestation of God as a fertility goddess), and having the freedom to manage his own household as well as in In relation to outsiders.

Darmanta, et al. (2013) explains that subak is essentially an autonomous institution of indigenous peoples, meaning that subak communities have the freedom to manage their own 
households and in relation to outsiders. However, the autonomous nature of subak does not make a subak institution as a sterile institution without any interaction with other government agencies. Currently, there are various government programs that utilize subak as the target of the program.

Suyatna in Pitana (1993) mentions that traditional groups in Bali, especially banjar and subak, play an important role in supporting development programs. Thus it is very natural that the government utilize this institution to participate in the success of programs launched by the government.

Subak as a farmer institution that has been handed down from generation to generation has the strength and potential to be developed not only limited to regulate the irrigation system, but also in the field of economic business. When the issue to develop subak as economic institution (not just to control watering system), Subak Pulagan has been able to become a farmer institution that plays an important role in off-farm process or after harvest. Where Subak Pulagan has been able to accommodate the agricultural products of its farmers as members. Most of the other farmers institutions have not been able to accommodate the farmers' harvest, even if they do economic business, only limited to sales infrastructure for rice production to farmers.

Many advantages obtained by farmers when subak has been able to accommodate the harvest of farmers in Subak Pulagan. First, the farmers does not have to think about where to sell the crop to get a reasonable price. Second, in the process of harvesting and transporting, farmers can get help from other subak members. Third, farmers are exempted from the cost of performing rituals at the subak level.

The establishment of a philosophical agricultural agency with the aim to solve problems faced by farmers but can not be solved individually. The formation of farmer groups is a consolidated agriculture process, so it can produce optimally and efficiently. This is because that in consolidated farming in farmer groups, the procurement of production facilities and the sale of results can be done together. The objective is that the volume of production facilities purchased and the volume of yields sold become larger, so the procurement cost per unit of means and marketing per unit of yield becomes lower.

Farmer group itself is one effort to empower farmers to improve productivity, income, and welfare of farmers. Strictly, Nuryanti and Swastika (2011) mentioned that the existence of farmer groups is very important, where government and private parties can cooperate with member farmers by establishing partnerships. This means that cooperation can be in any form is expected to leverage the active role of the group to improve the level of economy or welfare of farmer group members.

The role of government to ensure the sustainability of food security, the government through research and development agencies can develop agricultural technology, in the hope of improving and streamlining the agricultural sector. Prabowo (2010) explains that technology development also includes aspects of institutional engineering, which encourage the development of institutional agribusiness and institutional in rural areas. Service to peasants in the reform era should be carried out in good and clean governance corridors, following the following principles: (a) empowering in the sense of improving the ability to analyze, make decisions, build access to resources and production facilities, and solve problems faced; (b) partifipative in producing appropriate technology, which involves farmers from planning, implementation, monitoring, evaluation and improvement; (c) provide an opportunity for the community to provide input; and (d) establishing good communication and cooperation between governments with various components of society to complement each other for mutual progress. Therefore, further Achmad (2005) mentions that the system that has been designed by the government for a centralized and instructive pattern, in this era of autonomy and globalization needs to be adjusted to a participatory pattern. This participatory pattern is one of them by empowering farmers to be active in developing farmer institutions. Through optimizing the role of government by empowering farmer institutions, it is expected to realize food security and farmers' welfare. 


\section{CONCLUSION}

In relation to the role of government, it is recommended that the government review the provision of direct assistance to individual farmers. Government programs should be through the introduction of new innovations in agriculture. In addition, the government program should also be through the farmer institution considering the farming in Bali Province, including in Subak Pulagan generally done on a small scale so that the provision of assistance will be more optimal if through an institution, so it can be used together for the progress and welfare of local farmers.

Agricultural institutions, especially subak, are advised to increase their capabilities. Considering that most government programs are conducted by involving farmers' institutions, not directly to individual farmers. Government in conducting activities in subak, especially located in world heritage area, should cooperative with subak. The role of subak institutions is very central and will also support the implementation of various government programs.

\section{REFERENCES}

1. Agustian, A., S. Friyatno, Supadi dan A. Askin. (2003), "Analysis of Agro-Industry Development of Plantation Commodity (Coffee and Coconuts) in Supporting Agricultural Sector Competitiveness", Seminar Paper on Research from Center of Agricultural SocioEconomic Research and Development. Bogor.

2. Albert, M. and Hannel, R. (2005), Traditional Welfare Theory. www.zmag.org/books/1/html.

3. Albrecht, Hartmut et al. (1989), Agricultural Extension: Basic Concepts and Methods. Eschborn: Deutsche Gesellschaft fut Technische Zusammenarbeit (GTZ).

4. Anantayu, Sapja. (2011), "Farmers Institutional: Role and Strategy to Develop Its Capacity", SEPA, Vol. 7 No. 2, Pebruari 2011.

5. Anggraini, Selvi. (2011), "Improving Communication System and Agricultural Institutional System as Efforts to Increase Farmers Income Welfare: Avoiding the Role of Brokers", Paper of KPM, Bogor: Department of Science, Communication and Community Development, Faculty of Human Ecology, Bogor Agricultural Institute.

6. Darmanta, I N., I Ketut Sudiatmika, I Nyoman Pursika. (2013), "The role of Subak Pulagan-Kumba in Oversoming Agriculture Land Conversion in Tampaksiring Village of Tampaksiring District, Gianyar Regency, Bali”, Article, Singaraja: University of Pendidikan Ganesha.

7. Euis, Sunarti. (2007), Indicator of Families Welfare. http://euisunarti.staff.ipb.ac.id.

8. Ferdinand, A. (2012), Research Methodology of Management, Semarang, Diponegoro University Press.

9. Garkovich, Lorraine E. (1989), "Local Organizations and Leadership in Community Development', Community Development in Perspective, Editor: James A. Christenson dan Jerry W. Robinson Jr. lowa: lowa State University Press.

10. Hair, et al. (1998), Multivariate Data Analysis, Fifth Edition, Prentice Hall, Upper Saddle River: New Jersey.

11. Hayami, Yujiro dan Vernon W. Ruttan. (1985), Agricultutal Development (An International Perspective), Revised and Expanded Edition, Baltimore dan London: The Johns Hopkins University Press.

12. Hindriks, Jean, dan Gareth D. Myles. (2006), Intermediate Public Economics, MIT Press Book.

13. Jamal, H. (2008), "Chance the Orientation of Agricultural Counceling", Jambi Express Online, Jambi: Office of Research and Development of Jambi Province.

14. Jeckoniah, J., Mdoe, N., Nombo, C. (2013), "Mapping of Gender Roles and Relations Along Onion Value Chain in Northern Tanzania", International Journal of Asian Social Science, Vol. 3 (2) : 523-541.

15. Kemendikbud. (2013), Subak as World Heritage, http://kebudayaan.kemdikbud.go.id. 
16. Kherallah, Mylene dan Johann Kirsten. (2001), "The New Institutional Economics: Applications for Agricultural Policy Research in Developing Countries", MSSD Discussion Paper. No.41, June 2001, Washington: International Food Policy Research Division.

17. Listyati, D., A. Wahyudi, AM Hasibuan. (2014), "Instituional Strengthening to Increase Bargaining Power of Farmers in Cacao Marketing System", Jurnal TIPD, Nomor 1, Volume 1, Maret 2014.

18. Mosher, Arthur T. (1991), Getting Agriculture Moving, New York: Frederick A. Praeger, Inc. Publisher.

19. Nuryanti, Sri dan Dewa KS Swastika. (2011), "The Role of Agricultural Group in Implementing Agricultural Technology", Forum Penelitian Agro Ekonomi, Volume 29 No. 2, Desember 2011: 115-128.

20. Pitana, I Gede. (1993), Subak as Irrigation System in Bali, A Canang Sari, Denpasar: Upada Sastra.

21. Prabowo, Rossi. (2010), "Government Policy in Realize Food Sovereignty", Jurnal IImuilmu Pertanian, Vol 6, No 2.

22. Purwanto, Mat Syukur, dan Pudji Santoso. (2007), Farmers Institutional Strengthening in Supporting Agricultural Development in East Java, East Java: Balai Pengkajian Teknologi Pertanian Malang.

23. Sarita, A.F. I Wayan Windia dan I Wayan Sudarta. (2013), Farmers Perception About the Inscribe Subak as World Culture Heritage (Case Study in Subak Pulagan, Tampaksiring District Area of Gianyar Regency), E-Jurnal Agribisnis dan Agrowisata, Vol. 2, No. 4, Oktober 2013.

24. Sarjana dan Munir EW. (2008), "Farmers Household Income Analysis With Rural Economic Agricultural Indicator Approach", Paper Presenting in National Conference of Agricultural and Rural Development: Threat and Opportunity to Increase Farmers' welfare, 19 November 2008, Bogor.

25. Saskara, I.A. and A.A.I.N. Marheni. (2017). The Role of Social Capital and Business Strategies in Developing the Business of Banten to Increase Balinese Women's Employment. Journal of Comparative Asian Development. Vol.16, No.1, 68-86. http://dx.doi.org/10.1080/15339114.2017.1292930.

26. Sesbany. (2009), "Farmers Institutional Welfare to Increase Farmers Bargaining Power".

27. Suasih, N.N.R., I.A.N. Saskara, I N. Mahaendrayasa, and M.K.S.Budhi. (2017). Which One is Stronger to Affect Innovation Adoption by Balinese Farmers: Government Role of Local Wisdom? Journal of Sustainable Development. Vol.10, No.3; 2017. https://doi.org/10.5539/jsd.v10n3p993.

28. Subagia. (2011), Plan to be World Heritage, Farmers in Jatiluwih don't be An Object. http://www.beritabali.com.

29. Sulistyanto, Bambang. (2012), "World Culture Heritage, Threat and Opportunity of Bali", Paper Presenting in Sudamala Culture Dialogue, http://www.journalbali.com.

30. Suradisastra , K. dan A. Dariah. (2013), "Mapping of Local Wisdom and Social Capital in Dry Land Agricultural", p.103 - 122, Prospect of Dry Land Agriculture in Supporting Food Sovereignty, Badan Litbang Pertanian, Kementerian Pertanian: IARRD Press.

31. Syahyuti. (2003), Analyse Institutional Concept: Developing Strategy and Implementing in Agricultural Research, Bogor: Research and Development Center of Agriultural SocioEconomic.

32. Uphoff, Norman Thomas. (1986), Local Institutional Development: An Analytical Sourcebook With Cases, Kumarian Press.

33. Windia, W. dan WAA Wiguna. (2012), Subak as World Cultural Heritage, the Cultural Landscape of Bali Province Inscribed on the World Heritage List in 2012.

34. Yustika, Ahmad Erani. (2010), Institutional Economic (Definition, Theory and Strategy), Second Edition, Malang: Bayumedia Publishing.

35. Zuraida, D. dan J. Rizal. (1993), Threat and Opportunity of Local Autonomy, Malang: Brawijaya University. 